\title{
CONDOMÍNIO FECHADO: PARAÍSO CÍNICO
}

\author{
Private condominium: cynical paradise
}

\author{
Tony Hara ${ }^{1}$ \\ Gabriel José Pochapski ${ }^{2}$
}

\begin{abstract}
RESUMO
Compreendendo que os seres humanos são um efeito dos espaços que criam, este texto procura traçar o percurso histórico dos condomínios contemporâneos e suas relações com o cinismo moderno, entendido por Peter Sloterdijk como a insolência e a desfaçatez das elites. Discutiremos como a história dos condomínios abrange elementos antigos e modernos marcados pela figura do paraíso, e como a constituição desses espaços de luxo e segurança estimulam a normalização do cinismo ético-político na atualidade.
\end{abstract}

Palavras-chave: Cinismo Moderno; Condomínio; Espaços; História; Paraíso.

\begin{abstract}
Understanding that human beings are an effect of the spaces they create, this text seeks to analyze the historical path of contemporary condominiums and their relations with modern cynicism, understood by Peter Sloterdijk as the rudeness and dissimulation of elites. We will discuss how the history of condominiums presents ancient and contemporary elements marked by the figure of paradise and how the constitution of these spaces of luxury and security stimulates the normalization of the current ethical-political cynicism.
\end{abstract}

Keywords: Modern cynicism; Condominium; Spaces; History; Paradise.

\footnotetext{
1 Doutor em História pela Universidade Estadual de Campinas (UNICAMP) e, atualmente, é pós-doutorando em História na mesma instituição. E-mail: hara.tony@ gmail.com

2 Doutorando em História na Universidade Estadual de Campinas (UNICAMP) e bolsista da Fundação de Amparo à Pesquisa do Estado de São Paulo - FAPESP (Processo 2019/17278-8). E-mail: gabriel_pochapski@ gmail.com.
} 
Antes de se tornar a morada eterna dos bem-aventurados cristãos, o paraíso era algo bem mais modesto: um jardim cercado por um muro. $\mathrm{O}$ filósofo Santiago Beruete rastreou a origem do termo que vem do antigo persa, pairidaeza. Palavra composta por pairis que significa "em torno", e daeza, "argila, adobe, muro"; daí pairidaeza, "muro circundante", "área murada" (BERUETE, 2016, p. 22).

No fundamento do paraíso, temos, portanto, o muro, a demarcação de um espaço. Como diz o filósofo jardineiro: "não há jardim sem fronteiras. Desde a origem mais remota, o jardim é entendido como um espaço cercado, delimitado, separado da natureza selvagem, pouco importa se por muros de pedra, cercas vivas, estacas ou paliçadas" (BERUETE, 2016, p. 22).

Afastar-se dos perigos da natureza indomável, delimitar um espaço protegido e apropriado ao cultivo das coisas humanas - o paraíso murado faz parte dessa busca primordial por um abrigo na vastidão do mundo. Peter Sloterdijk nos lembra que "todas as gerações antes da nossa estavam cientes de que você não pode acampar do lado de fora, na natureza. Os acampamentos dos ancestrais do homem, datando de milhares de anos, já indicavam que eles estavam distanciando a si mesmos de seus arredores" (SLOTERDIJK, 2015, p. 86).

É possível imaginar o paraíso antigo como um monumento exuberante desse processo de distanciamento do mundo exterior e, ao mesmo tempo, de organização de um mundo interno. Estes espaços floresceram inicialmente sob o sol e a luz dos impérios que despontaram às margens do Tigre e do Eufrates, na Idade do Bronze. Os jardins suspensos da Babilônia, os perfumados jardins Persas, os parques de caça dos Aquemênidas e dos Medos, monumentos imperiais construídos pelos povos subjugados e conduzidos ao duro trabalho de erguer os muros, de alterar o curso dos rios, rasgando na terra os canais de irrigação que fizeram a vida brotar na paisagem desértica.

Os paraísos mesopotâmicos expressavam o poder do soberano sobre a natureza e sobre os homens. Mas, tratava-se também, como observa Michel Foucault, de um lugar de utopia. Ao descrever o desenho tradicional dos jardins persas, o filósofo reconhece o impulso utópico que conduz os soberanos à construção de um mundo perfeito aqui na Terra; um mundo em miniatura, reduzido ao essencial indispensável à perfeição. No centro do jardim retangular, o espaço sagrado, a fonte da vida. Nos quatro quadrantes que formam o jardim - que simbolizam os quatro elementos da vida e os 
quatro cantos da Terra - "toda a vegetação exemplar e perfeita do mundo reunida" (FOUCAULT, 2013, p. 24).

Séculos antes da ascensão do império Persa e de seus jardins utópicos, os soberanos da Assíria, pastores que se tornaram exímios guerreiros, já mandavam trazer plantas e animais vindos das regiões mais longínquas do reino, por volta do ano 1.100 a.C. Cada ser vivo, selecionado e cultivado no jardim imperial, simbolizava um território conquistado. Ao contemplar a paisagem, o rei desfrutava não só da beleza da vida natural, mas também dos espólios de campanhas vitoriosas sobre os inimigos.

No interior daquela área murada, um mundo organizado, controlado e protegido despontava sol a sol, refrescado pelas águas que corriam por canais, fontes e lagos. Esse era o Paraíso das antigas elites imperiais.

\section{O Palácio de Cristal}

Na modernidade surge o Império do capital e novos soberanos com a mesma sede por territórios e tesouros escondidos nas colônias. Da antiga Mesopotâmia, solo da revolução agrícola, à Europa da revolução industrial, o paraíso - entendido aqui como espaço murado -, sofreu uma profunda transformação. No interior do antigo jardim a céu aberto ergueu-se uma estufa gigantesca de vidro e ferro fundido, onde mercadorias do mundo todo foram reunidas e aclimatadas.

O Palácio de Cristal, sede da primeira Exposição Universal realizada em Londres, foi projetado por um jardineiro especialista em estufas, Joseph Paxton. O edifício construído na capital do Império Britânico abrigou no ano de 1851, 17 mil expositores vindos das 30 colônias espalhadas pelo globo, subjugadas sob a bandeira do livre comércio e do liberalismo econômico. Em meio aos terraços, fontes e plantas trazidas de todo o planeta, seis milhões de visitantes entraram em contato com as novidades e maravilhas da arte, da ciência e da tecnologia, linhas de força estratégicas e decisivas para a pretensão universalizante da Europa Ocidental.

Ao refletir sobre esse edifício monumental inaugurado pela jovem rainha Vitória, o filósofo Peter Sloterdijk afirma que o Palácio de Cristal "revelou a tendência da época para transformar a natureza e cultura em 
assuntos de interior" (SLOTERDIJK, 2008, p. 185). Como se dizia na época, um passeio pelas dependências do Palácio era como dar uma volta ao mundo sem sair do lugar. Walter Benjamin já havia percebido tais aspectos em seu trabalho sobre as passagens cobertas por estruturas de ferro e vidro, que transformaram as vias urbanas de Paris em charmosos interiores. Naqueles espaços protegidos do sol, da chuva e da neve, consumidores e mercadorias encontraram seu aconchego. O que havia de melhor do mundo exterior era trazido para o mundo interior das passagens, onde a elite burguesa da época era instruída por reclames, propagandas e vitrines irresistíveis (BENJAMIN, 1997, p. 72). A alma do negócio, nesses espaços fechados, passou a colonizar a alma dos consumidores.

Com o fim das Exposições Universais, o Palácio de Cristal foi transformado em um parque de lazer indoor com espetáculos culturais e exposições comerciais. Um importante equipamento urbano destinado à educação das massas, instruídas através do incitamento contínuo ao hedonismo vulgar e ao amor às mercadorias. Um certo cinismo frívolo também foi difundido de forma lisonjeira no interior da estufa de cristal. O cliente era tratado como "o" soberano do Império, que tinha o direito de colocar seus caprichos acima das dores e injustiças do mundo. Muitos tinham consciência de que a mercadoria que ali encantava foi trazida para dentro do palácio por uma cadeia de violências, não só nas colônias como no chão das fábricas. Mas esses clientes bajulados como reis aprenderam a dizer: "Ah! A vida é assim... A vida é para quem pode."

Cada cliente é rei e massa ao mesmo tempo no interior do Palácio. Quarenta, cinquenta mil pessoas passeando pela estufa climatizada, vendo e sendo vistas no habitat artificial das mercadorias. Com o jardineiro Paxton, o Império encontrou o protótipo de seus templos populares, o Shopping Center - contribuição ianque para a expansão dos negócios imperiais.

Como observa Peter Sloterdijk, o Palácio de Cristal inaugurou uma nova "estética da imersão", que triunfou na modernidade. Os técnicos e as empresas a serviço do Império do capital entenderam que a vida social produtiva e frívola deveria ser cultivada em interiores expandidos e controlados (SLOTERDIJK, 2008, p. 185). Resorts, parques temáticos, arenas esportivas, shoppings, todos esses equipamentos ligados ao entretenimento ainda fazem uso da estética da imersão concebida no interior da estufa do jardineiro Paxton.

Não é surpreendente que essa forma de ocupação do espaço tenha influenciado também o nosso jeito de morar e de perceber os espaços ao 
nosso redor. Os condomínios fechados de alto padrão, que se espalham no entorno dos grandes centros urbanos, são máquinas de imersão. Em suas versões mais sofisticadas, esses empreendimentos imobiliários oferecem aos moradores a possibilidade de isolamento total do mundo exterior. Habitar no interior da estufa, construir uma morada no centro do jardim. Muitos clientes tratados como soberanos pela sedução do marketing comprarão a ideia de que isso é "viver no Paraíso".

\section{O Condomínio}

Michel Foucault diz numa entrevista que "seria preciso fazer uma 'história dos espaços' que seria ao mesmo tempo uma 'história dos poderes', que estudasse desde as grandes estratégias da geopolítica até as pequenas táticas do habitat" (FOUCAULT, 1979, p. 212). Para o filósofo, os espaços seriam atravessados por embates, por estratégias e por dimensões políticas marcadas pela ação do tempo. As mudanças espaciais, por mais simples que sejam, sinalizam a emergência de novos problemas e uma configuração do presente cuja historicidade deveria ser analisada de forma detalhada. Neste sentido, assim como os jardins antigos e o Palácio de Cristal, a história dos condomínios horizontais fechados é constituída de atravessamentos e de dinâmicas temporais que estabelecem os seus contornos e os seus efeitos na atualidade.

O primeiro condomínio residencial fechado, afastado do centro e destinado à elite, construído no Brasil foi o Alphaville; projeto imobiliário iniciado em 1973, nas proximidades da cidade de Barueri. Hoje, Alphaville é formado por vários núcleos residenciais murados, um conjunto de edifícios de escritórios e um centro comercial estabelecido ao redor de um grande shopping center. Os muros de cada núcleo residencial têm uma altura padrão de três metros e meio, e a população cercada é estimada em 35 mil almas.

O nome do empreendimento, curiosamente, foi retirado de um filme de Jean-Luc Godard. Na ficção, Alphaville era uma cidade distópica, controlada por um computador, o Alpha 60, programado para localizar e exterminar os moradores que sentiam algo ou que se emocionavam. $\mathrm{O}$ 
projeto visava abolir da cidade os sentimentos e as emoções humanas, transformando-a numa espécie de cemitério dos vivos.

As ambições dos agentes imobiliários que criaram o Alphaville de Barueri eram mais modestas, apesar do desejo de ir além do trivial negócio imobiliário. A antropóloga Teresa Caldeira aponta que os empreendedores criaram um novo conceito de moradia, amplamente divulgado e influenciado pelos instrumentos do marketing e da publicidade. Segundo a pesquisadora, a propaganda dos novos paraísos na Terra articulava cinco elementos básicos: segurança, isolamento, homogeneidade social, equipamentos e serviços (CALDEIRA, 2000, p. 10).

Apresentado como refúgio, bunker ou enclave fortificado, o condomínio foi vendido como território isolado, como abrigo que deixava para o lado de fora do muro não a natureza selvagem, mas a selvageria da miséria fabricada pela própria dinâmica do progresso econômico desigual que se vivia na época.

Um exemplo emblemático dessa dinâmica histórica e espacial, ligada à fabricação da miséria e da desigualdade social, foi o processo de formação da favela de Paraisópolis, hoje com 100 mil moradores. Embora essa área tenha sido ocupada ilegalmente desde 1950, foi na década de 1970 momento de emergência dos condomínios verticais -, que a favela cresceu e expandiu os seus limites. Como explica a pesquisadora Raquel Rolnik, na era do chamado "milagre econômico", a cidade de São Paulo começou a ganhar ares de metrópole, mas com um modelo de desenvolvimento profundamente desigual e excludente (ROLNIK, apud. SOUZA e BARIFOUSE, 2019, s/p). Ao povo que levantou prédios e muros, ao exército de domésticas, migrantes e biscateiros que serviam à classe média instalada nos novos apartamentos do Morumbi e arredores, não restou outra saída senão a favela, o mercado paralelo e irregular das moradias.

Do mesmo modo, não se pode ignorar que os condomínios horizontais de luxo, afastados da cidade se tornaram verdadeiros objetos de desejo da elite somente na década de 1980. Período em que se percebe nas ruas os efeitos do dito "milagre econômico" propagandeado pela Ditadura Militar: uma concentração de renda brutal e a massificação da miséria.

Ao longo da década de 80, o fenômeno dos moradores de rua torna-se uma problemática da cidade de São Paulo, agudizado pela crise econômica. Chegam às ruas pessoas recém- 
desempregadas ou cujas condições econômicas não permitem o acesso a condições de moradia digna. A sua presença foi paulatinamente percebida nas calçadas, jardins, viadutos, praças e parques (ESQUINCA, 2013, p. 23).

Nesses mesmos espaços públicos de São Paulo perambulava um outro personagem urbano que provocava medo e desconforto nos anos 80: o menino de rua. De acordo com o professor e juiz de direito, Umberto Sudbrack, os meninos de rua foram elevados à categoria de "inimigos da sociedade" no período de redemocratização do país, e se tornaram alvo de grupos de extermínio, "pagos por comerciantes e outros setores da sociedade, aos quais a ação ou mesmo a simples presença deles perto de seus estabelecimentos causava transtorno e prejuízo" (SUDBRACK, 2004).

A percepção do espaço público como cenário de guerra e degradação, colaborou para a transformação do condomínio fora da cidade em uma mercadoria efetivamente desejada; um passaporte, uma senha de acesso a um outro mundo, protegido pela distância, pelos muros e pelos aparatos de segurança privada.

Ora, Foucault nos faz recordar que os militares foram os primeiros grandes administradores dos espaços. Montar um forte, construir muralhas e fossos, definir regiões de intervenção e de domínio, foram procedimentos de guerra que informaram as relações que passamos a desenvolver com o urbanismo, com as arquiteturas e com aquelas espacialidades mais próximas de nós, como as casas (FOUCAULT, 1979, p. 157-161). Os muros do condomínio lembram, obviamente, as muralhas das fortalezas, dos fortes e dos enclaves fortificados. A imagem do enclave, isto é, um território distinto inserido dentro dos limites de um outro território, foi amplamente usada pela pesquisadora Teresa Caldeira em seu estudo sobre a Cidade de muros (2000). "Os enclaves são - escreve a antropóloga - opostos à cidade, representada como um mundo deteriorado no qual não há apenas poluição e barulho, mas, o que é mais importante, confusão e mistura, isto é, heterogeneidade social" (CALDEIRA, 2000, p. 12).

Os condomínios horizontais ganharam a cena no mercado como uma forma seletiva de refúgio, como uma oportunidade de distanciamento da mistura e da heterogeneidade social existente nas ruas da cidade. Dizendo de maneira simples aquilo que todos sabem: o muro do condomínio serve para deixar o pobre para o lado de fora, longe da vista do sujeito confinado. 
O muro indica o reconhecimento da desigualdade social e um modo de enfrentar esse problema - reforçando e valorizando a desigualdade entre a cidade suja e caótica e o condomínio, mundo exclusivo de prazer entre pessoas que se percebem como iguais na riqueza. Assim, partindo de uma premissa de igualdade intramuros, tal como analisou Christian Dunker, os moradores do condomínio passam a conceber o espaço em que vivem como um "falso universal". Para o psicanalista, a suposta igualdade dos condôminos se manifesta no pouco interesse por aqueles que vivem fora daquelas fronteiras, uma vez que a semelhança é percebida somente entre os que estão imersos e implantados na mesma área de confinamento (DUNKER, 2015, p. 37).

Em um primeiro olhar, considerar o condomínio como uma ilha cercada por um mar de misérias pode parecer exagerado, mas retrata a estratégia usada pelo Império do capital no combate aos efeitos de seu domínio. O capitalismo, escreve Gilles Deleuze em seu Post-scriptum sobre a sociedade de controle (1990), "manteve como constante a extrema miséria de três quartos da humanidade, pobres demais para a dívida, numerosos demais para o confinamento: o controle não só terá que enfrentar a dissipação das fronteiras, mas também a explosão dos guetos e favelas" (DELEUZE, 1992, p. 223). O enclave fortificado é uma resposta do poder à multiplicação dos guetos e favelas. No momento em que se vivia, segundo Deleuze, uma "crise generalizada de todos os meios de confinamento", as empresas que vendiam "um novo jeito de morar", apostaram seu capital na reforma e na repaginação dos espaços confinados, agora equipados com as amenities.

Nas propagandas de condomínios de luxo a palavra "amenidades" indica equipamentos e serviços oferecidos pelo empreendimento. Campos de futebol, arenas, spas; fazendinha, centro equestre, centro comercial, centro de produtos orgânicos; piscina para a prática do surf; piscinas cobertas e descobertas. Amenidades.

No interior da fortaleza vibra um Palácio de Cristal repleto de amenidades. O condomínio de luxo conjuga essas duas formas espaciais: uma mais ligada ao controle dos que vem de fora, o muro; e a outra mais ligada ao controle da população interna, as amenidades. Peter Sloterdijk (2015, p. 86) diz numa entrevista que "Nós temos que falar de espaços porque os humanos são, eles mesmos, um efeito do espaço que criam". Se o sujeito é um efeito do espaço transformado, vale a pergunta: que tipo de humano é desenvolvido no interior dos condomínios? 


\section{Paraíso cínico}

Podemos pensar o condomínio como uma espécie de incubadora de indivíduos "empresas". Empresas tal como Michel Foucault definiu em suas análises sobre o neoliberalismo americano: a "empresa" como um modelo de relações sociais que utiliza como parâmetro o modelo econômico, o modelo do investimento-custo-lucro, na avaliação das relações do indivíduo consigo mesmo, com o outro e com o mundo. Indivíduo-empresa, empresário de si, sujeito que administra a si mesmo como "capital humano". Investimentos educativos, afetivos, esportivos, culturais, etc., para maximizar a capacidade de fazer dinheiro. É a multiplicação dessa forma empresa no interior do corpo social que constitui o alvo da política neoliberal (FOUCAULT, 2008).

Uma das questões debatidas pelos teóricos do neoliberalismo, na década de 1970, colocava em cena a questão: que tipo de investimento é necessário para a constituição de um capital humano, de uma "competênciamáquina" capaz de produzir renda? Eles sabiam que os investimentos educacionais eram apenas uma parte do negócio. E passaram fazer análises e cálculos tendo em vista outros tipos de investimentos, como, por exemplo, o número de horas que uma mãe passa ao lado do filho, o nível cultural dos pais, os estímulos recebidos pela criança, as atividades ao ar livre, e por aí vai... Para os neoliberais, tudo isso vai contribuir para formar um capital humano. Daí a importância, a valorização do ambiente em que se vive, gerador de estímulos que vão interferir na constituição da "competência-máquina".

As amenidades implantadas no interior do condomínio são geradoras de estímulos permanentes e variados. Da hortinha orgânica para as crianças às piscinas com ondas, as amenidades atendem a demanda das elites por experiências exclusivas. Acredita-se que essas vivências imersivas em ambientes controlados vão produzir o diferencial entre os indivíduosempresas na disputa por um lugar ao sol no mercado da vida. Uns irão chamar esse diferencial de mérito; a maioria não acredita nisso.

As amenidades desempenham um papel importante na formação do capital humano, mas o muro, o habitar no interior de uma fortaleza, também produz seus efeitos no processo de constituição do humano. A estratégia de lidar com a desigualdade social, reafirmando concreta e ostensivamente a própria desigualdade, cria um ambiente propício para o desenvolvimento do cínico vulgar. 
O filósofo Peter Sloterdijk descreve esse tipo de cinismo moderno:

O senhor cínico retira a máscara, sorri para seu frágil adversário - e o oprime. C'est la vie. A Nobreza obriga. É preciso haver ordem. [...] O cinismo dos senhores é uma insolência que trocou de lado. Aqui não é Davi que provoca Golias, mas os Golias de todos os tempos que mostram aos Davis corajosos, mas sem perspectiva, onde ficam os de cima e os de baixo (SLOTERDIJK, 2012, p. 166).

O que define o cinismo moderno, no entendimento de Sloterdijk, é que a insolência mudou de lado. No cinismo antigo, a palavra insolente, franca e destemida era sempre dirigida ao poderoso. O golpe partia, com coragem, de baixo para cima. Podemos relembrar, por exemplo, a cena de Diógenes com Alexandre, o Grande. - Peça o que quiseres, ó Diógenes? Saia do meu sol! A mensagem do filósofo insolente era essa: tenho tudo o que necessito, não estou à venda, nem disponível para o aluguel imperial. Entretanto, no cinismo moderno, o senhor toma a palavra franca e a utiliza com insolência para atormentar o fraco e colocá-lo no seu devido lugar. Lugar do subalterno, do submisso, que pode até ter razões morais elevadas e superiores, mas impotentes, inúteis em certas batalhas.

Um caso policial ocorrido em maio de 2020, num dos condomínios de Alphaville, ilustra, com um certo exagero, a atitude cínica do senhor vulgar. Ao receber a polícia, acionada pela própria esposa, vítima de agressões, o senhor fulano não sorri, mas se dirige até a porta de sua casa e dispara contra os policias uma artilharia de ofensas:

Não pisa na minha calçada, não pisa na minha rua, eu vou te chutar na cara, filho da puta. Seu merda. Você é um merda de um PM que ganha mil reais por mês, eu ganho trezentos mil por mês. Eu quero que você se foda, seu lixo do caralho. Você pode ser macho na periferia, mas aqui você é um bosta. Aqui é Alphaville, mano! (Transcrição da fala publicada pelo site Metrópoles, $2020, \mathrm{~s} / \mathrm{p})$ 
Ao tornar a desigualdade um fator estruturante, os Golias de sempre ficam cada vez mais desinibidos para professarem um modelo de verdade intramuros. No interior do condomínio, tudo o que há de melhor do mundo; fora dele, tudo o que há de pior - miséria, sujeira, violência, caos. No interior, os meus iguais, aqueles que mandam e podem; lá fora estão todos aqueles que querem, mas querer não é poder. Aqui é Alphaville, mano! O dinheiro manda; e você não faz parte desse mundo!

Esse tipo de cinismo surtado, trabalhado no escândalo, tem aparecido com mais frequência nos noticiários, provocando fortes reações e comoções nas redes sociais. Mas é preciso dizer que nem todos os cínicos modernos são arrogantes e agressivos. Na maioria das vezes, eles se contentam em mentir. Não é preciso afirmar a inferioridade do outro, como fez o fulano de Alphaville, pois a mentira e o bom-trato bastam para lidar com os contratempos do mundo exterior.

Em uma entrevista, Deborah Danowski apresenta uma situação que exemplifica essa atitude cínica mais discreta. A filósofa rememora alguns dados e pesquisas sobre o colapso climático que se aproxima e que assistimos sem saber como reagir. As informações não são exatamente novas, mas sempre aterradoras. Ela lembra que vivemos a sexta grande extinção em massa, numa taxa bastante acelerada que pode fazer desaparecer três quartos das espécies que vivem na Terra atualmente; lembra que o aquecimento global vai atingir primeiro e com mais intensidade, as populações mais pobres; menciona a pesquisa que indica 20 empresas como responsáveis por um terço de todas as emissões globais de carbono; e uma outra pesquisa que destaca as operações de 100 grandes companhias, responsáveis por $70 \%$ das emissões que estão mudando o clima do planeta. E arremata a entrevista, com o seguinte raciocínio:

As elites sabem muito bem, e há bastante tempo, o que está acontecendo, sabem que não há mundo para todos. Essa elite nem se preocupa mais em fingir que pretende implantar um Estado de bem-estar social. Já faz tempo que eles sabem que não vai dar e escolheram mentir para proteger apenas a si próprios, e para isso tem sido fundamental esse negacionismo financiado há décadas pelas maiores empresas de combustíveis fósseis, porque no fundo eles já abandonaram as pessoas (DANOWSKI, 2020, s/p). 
O condomínio, como dissemos anteriormente, reúne elementos do Palácio de Cristal, que o mercado imobiliário chama atualmente de "amenidades". O campo de golfe, as áreas florestais, os lagos artificiais, os charmosos centrinhos inspirados em Carmel ou Hamptons, com galerias de arte, alta gastronomia, lojinhas de grifes internacionais... Todos esses espaços e serviços funcionam como dispositivos de imersão; e provocam uma espécie de anestesiamento dos sentidos. Anestesia no sentido original grego: an (ausência/privação), aísthesis (sensação/percepção). Ausência de sensação do outro, privação da percepção do diferente. Os dispositivos de imersão facilitaram enormemente a ação dos cínicos discretos, captados pela análise sensível de Deborah Danowski. É fácil abandonar as pessoas que não são sentidas, percebidas, que, no fundo, inexistem.

Um dos efeitos mais desconcertantes desse espaço de confinamento das elites é a cristalização de um único sentido para a existência: fazer dinheiro. "Possuir dinheiro é a maior virtude e o maior dever humano". Dostoiévski (2011, p. 112) anotou essa frase em seu diário de viagem, ao observar os burgueses franceses que ele detestou conhecer em 1862. Este princípio moral flagrado pelo escritor russo evoluiu de forma tão monstruosa, que houve uma inversão ou uma mutação da posse. Não é o homem que possui o dinheiro; é o dinheiro que possui o homem. O homem está a serviço de suas posses, é seu escravo.

$\mathrm{O}$ anestesiamento provocado pelos dispositivos de imersão preservou apenas as percepções úteis para o funcionamento da "competênciamáquina", isto é, o faro para os negócios e o sentimento de amor às mercadorias. De uma certa maneira, o Alfa 60 de Godard triunfou na era das subjetividades neoliberais.

O cinismo de fino trato praticado pelo presidente de uma corretora de valores é um exemplo desse triunfo. No dia 4 maio de 2020 - quando 7.321 pessoas haviam falecido em decorrência da Covid-19 -, o jovem líder do mercado de ações procura acalmar seus clientes-investidores, em uma live organizada pelo Estadão. Ele diz: "Acompanhando os nossos números, eu diria que o Brasil está bem. O pico da doença já passou quando a gente analisa a classe média, classe média alta" (MOURA, 2020, s/p). O economista estava correto. No dia 27 julho (mais de 87 mil mortos), a manchete do Valor Econômico anunciava: "Bilionários brasileiros enriqueceram US\$ 34 bilhões a mais na pandemia" (MARTINS, 2020, s/p).

O triunfo dos homens escravizados pelo dinheiro não pode ser avaliado em números, em cifras. A vitória dessa elite cínica tem a ver 
com a nossa incapacidade de reagir a essa concentração de renda brutal em tempos de crise sanitária e econômica. Situação idêntica àquela vivida nas lutas ambientais. Estamos cientes de que o modo de vida neoliberal é insustentável, de que colapso ecológico se aproxima, que a biodiversidade está sendo reduzida drasticamente, mas não sabemos como reagir, resistir, interromper esse processo.

Os Davis de hoje podem fazer uso da santa indignação contra os Golias de sempre, mas o jogo não muda. Como pergunta a antropóloga Rita Segato,

“Quem vai dizer 'não economize', 'não trabalhe', 'não produza riqueza'? Exortar o não enriquecimento não tem legitimidade porque a retórica branca venceu. [...] Práticas não-produtivistas, não competitivas nem concentradoras na linguagem hegemônica são qualificadas negativamente. A retórica dominante as desdenha" (SEGATO, 2021, s/p).

\title{
Adeus ao Paraíso
}

\author{
Até os meios insuficientes - infantis mesmo - podem \\ servir à salvação. \\ F. Kafka, O silêncio das sereias
}

Conta-se que Diógenes foi consultar o oráculo de Delfos. E lá recebeu a mensagem de Apolo que dizia algo como "descaracterize os valores correntes, adultere o valor da moeda". Seu pai cunhava as moedas da cidade de Sinope. Diógenes foi flagrado falsificando moedas. Foi julgado e condenado ao exílio, uma punição muito dura no mundo antigo. Ao receber 
a sentença, disse orgulhoso aos homens que o julgaram: - Pois bem, eu os condeno a ficarem aí aonde estão!

Dar às costas à elite, ao cinismo do condomínio, aos soberanos a serviço do Império do capital, não é a tarefa fácil. Isso significa mudar radicalmente os valores correntes. Mesmo do lado de fora do muro, nós fomos colonizados pela verdade que diz: possuir dinheiro é uma virtude e ganha-lo é um dever moral. Sonhamos com o conforto, com as amenidades e os privilégios, tal como sonharam os visitantes do Palácio de Cristal.

Seria necessário, de alguma maneira, atualizar o gesto de Diógenes. Dizer adeus ao Paraíso, ao mundo perfeito sonhado pelos antigos imperadores e reformado pelos empresários de si neoliberais. Talvez seja necessário aprender a desviar o olhar da grama verde do vizinho, desviar o olhar dos paraísos terrestres exibidos nas redes sociais pelos ricos \& famosos da moda. Desviar o olhar a fim de não nos tornarmos cúmplices dos senhores cínicos, que escravizados por suas posses, abandonaram as pessoas e o mundo além dos muros.

Diógenes, o Cão, foi um filósofo mendigo, sem teto, maltrapilho e livre, que depois do exílio foi parar em Atenas, por volta do ano de 340 a.C. Ele não fez nenhum voto de pobreza em nome de um Deus ou de uma ordem religiosa qualquer. No seu entendimento, o brilho e a promessa de fama, riqueza e poder eram seduções lançadas pela civilização a fim de conduzir os homens não no caminho da felicidade, mas do próprio progresso da civilização, especialmente de seus patronos e patrocinadores. Fama, riqueza e poder: "tudo isso não passa de compensação por algo que um Diógenes não se deixa privar: liberdade, clareza de espírito, alegria de viver" (SLOTERDIJK, 2012, p. 231).

Assim como Sócrates, Diógenes também incomodava os passantes atenienses com perguntas difíceis. Uma delas, reza a lenda, dirigida a um homem rico atarantado com os servos que carregavam a sua mudança. Não tem vergonha de possuir tantas coisas e não possuir a si mesmo? Para Diógenes, a riqueza está ligada à posse, ao domínio de si mesmo. E a pobreza, ao desejo ilimitado por tudo e qualquer coisa colocado à venda na vitrine da civilização. Uma lição talvez aprendida com Sócrates, que andando na praça do mercado admirava-se com a quantidade de coisas que ele não tinha necessidade alguma. Esse mundo, dizia Diógenes, é como um mercado na beira da estrada. E o viajante mais sensato e lúcido é aquele que passa por ele e compra apenas as poucas coisas necessárias para a jornada (NAVIA, 2009, p. 177). 
Essas velhas lições dos filósofos da vida simples e despojada podem soar aos nossos sentidos como discursos bem-intencionados, mas infantis, ingênuos, descolados da realidade e da lógica concorrencial que transformou em valores positivos, a inveja, a cobiça e o amor às mercadorias. Um passeio ligeiro pelo Instagram revela o quanto fomos ensinados a dar o nosso "coraçãozinho" às mercadorias, às paisagens turísticas, aos camarotes do espetáculo da vida que invejamos e cobiçamos. Hoje a vida é assim! - podem dizer os realistas. A vida é correria, é bater meta, é boleto todo mês, é fatura do cartão. Bem-vindo à vida real - que de simples não tem nada.

Em suas famosas Teses sobre o conceito de História, Walter Benjamim (1994, p. 224) define o perigo que ameaça tanto a existência da tradição como os que a recebem: "entregar-se às classes dominantes, como seu instrumento". Os realistas que consideram infantis as velhas lições sobre a vida simples, talvez não tenham consciência desse perigo. Ou, talvez, não percebam o trabalho silencioso da autoindulgência na produção do conformismo, que orienta suas leituras e pontos de vista sobre o real. Ou, talvez, mais simplesmente, falte imaginação para idealizar outros modos de vida, outras metas de felicidade aquém ou além das amenidades, do incremento do capital humano e dos muros do condomínio. Mas essa necessária idealização de uma vida simples, comprometida com as coisas mais próximas e pequeninas da vida mesma, é uma tarefa filosófica reconhecidamente árdua.

Viver simplesmente. - Um modo de vida simples é agora difícil: pede mais reflexão e inventividade do que mesmo as pessoas mais inteligentes possuem. A mais franca entre elas talvez diga: "Não tenho tempo para refletir tanto sobre isso. O modo de vida simples é um objetivo nobre demais para mim; esperarei até que pessoas mais sábias do que eu o encontrem" (NIETZSCHE, 2008, p. 253).

Do passado, Nietzsche se apropria de uma reminiscência da vida simples encarnada por um homem sábio. "O filósofo da opulência. - Um pequeno jardim, figos, porções de queijo e três ou quatro bons amigos - esta foi a opulência de Epicuro" (NIETZSCHE, 2008, p. 252). 
Para sobreviver do lado de fora dos muros, abandonados à própria sorte na luta contra os efeitos do colapso ecológico que se avizinha, é preciso dizer adeus às pairidaezas imperiais e aos enclaves fortificados. Desviar o olhar e reaprender a contemplar um jardim como o de Epicuro: território da conversa, do tempo para o outro, da partilha da alegria e do prazer de viver como alívio para dores da angústia. Epicuro inventou o seu jardim no momento de declínio de democracia ateniense e de ascensão das tiranias. Tempos instáveis e perigosos como o nosso que parecem exigir novas formas solidárias de ocupar o espaço, de habitar e lidar com a terra, com os vizinhos, com os amigos e com o outro, seja ele bicho, planta, água ou pedra. Um jardim filosófico, uma horta comunitária, um campo experimental que suscite encontros e acontecimentos, mesmo que ínfimos. Um jardim que nos faça acreditar e tomar posse do mundo novamente, apesar de tudo, e mesmo depois de tudo.

\section{Referências bibliográficas}

BENJAMIN, Walter. Sobre o conceito de história. In: Magia e técnica, Arte e política. São Paulo: Brasiliense, 1994. p. 222-232

. O Trabalho das Passagens. Cadernos de Filosofia Alemã. São Paulo, n. 3, p. 69-77, 1997.

BERUETE, Santiago. Jardinosofía: una historia filosófica de los jardines. Madrid: Turner Publicaciones, 2016.

CALDEIRA, Teresa Pires do Rio. Cidade de muros: crime, segregação e cidadania em São Paulo. São Paulo: Editora 34/Edusp, 2000.

DANOWSKI, Deborah. "Não tem mais mundo pra todo mundo." Pública, 5/05/2020. [Disponível em: https://apublica.org/2020/06/nao-tem-maismundo-pra-todo-mundo-diz-deborah-danowski/]

DELEUZE, Gilles. Post-scriptum sobre as sociedades de controle. In:

Conversações. São Paulo: Editora 34, 1992. p. 219-226. 
DOSTOIÉVSKI, Fiódor. O Crocodilo e Notas de Inverno sobre Impressões de Verão. São Paulo: Editora 34, 2011.

DUNKER, Christian Ingo Lenz. Mal-Estar, Sofrimento e Sintoma: uma psicopatologia do Brasil entremuros. São Paulo: Boitempo, 2015.

ESQUINCA, Michelle Marie Méndez. Os deslocamentos territoriais dos adultos moradores de rua nos Bairros Sé e República. Dissertação (Mestrado em Arquitetura e Urbanismo) - Universidade de São Paulo, São Paulo, 2013.

FOUCAULT, Michel. Microfísica do Poder. Rio de Janeiro: Editora Graal, 1979.

. O corpo utópico, as heterotopias. Posfácio de Daniel Deferth. São Paulo: n-1, 2013.

. Nascimento da Biopolítica: Curso no Collège de France (19781979). São Paulo: Martins Fontes, 2008.

KAFKA, Franz. O Silêncio das Serias. In: Narrativas do Espólio. São Paulo: Companhia das Letras, 2002. p. 104-106.

MARTINS. Arícia. Patrimônio líquido de bilionários brasileiros cresceu US\$ 34 bilhões na pandemia, diz Oxfam. Valor Econômico, 27/07/2020. (Disponível em: https://valor.globo.com/brasil/noticia/2020/07/28/ patrimonio-de-bilionarios-brasileiros-cresce-us-34-bi.ghtml].

MOURA, JÚLIA. Pico de Covid-19 nas classes altas já passou; o desafio é que o Brasil tem muita favela, diz presidente da XP. Folha de S. Paulo, 05/5/2020. [Disponível em: https://www1.folha.uol.com.br/ mercado/2020/05/brasil-esta-indo-bem-no-controle-do-coronavirus-e-piconas-classes-altas-japassou-diz-presidente-da-xp.shtml].

METRÓPOLES. Empresário insulta PM. Metrópoles, 30/05/2020. [Disponível em: https://www.metropoles.com/brasil/empresario-insulta-pmmerda-ganha-r-1-mil-por-mes-eu-ganho-r-300-mil].

NAVIA, Luis. Diógenes, o cínico. São Paulo: Odysseus Editora, 2009.

NIETZSCHE, Friedrich. Humano, Demasiado Humano II. São Paulo: Companhia das Letras, 2008.

SEGATO, Rita. A vida transformada em coisa. n-1 Edições, 2021. [Disponível em: https://www.n-1edicoes.org/a-vida-transformada-em-coisa]. 
SLOTERDIJK, Peter. Palácio de Cristal: para uma teoria filosófica da globalização. Lisboa: Relógio D’Água, 2008. . Crítica da Razão Cínica. São Paulo: Estação Liberdade, 2012. . Teoria das Esferas: conversando comigo mesmo sobre a poética do espaço. Redescrições, Rio de Janeiro, ano VI, n. 1, p.86-105, 2015.

SOUZA, Felipe, BARIFOUSE, Rafael. Paraisópolis: como um loteamento de alto padrão virou a $2^{\mathrm{a}}$ maior favela de SP. BBC News Brasil, 8/12/2019. [Disponível em: https://www.bbc.com/portuguese/brasil-50694377].

SUDBRACK, Umberto Guaspari. O extermínio de meninos de rua no Brasil. São Paulo em Perspectiva. São Paulo, v. 18, n. 1, 2004. [Disponível em: https://www.scielo.br/scielo.php?script=sci_ arttext\&pid=S0102-88392004000100004].

RECEBIDO EM: 05/04/2021

APROVADO EM: 10/04/2021 